Research Article

\title{
Performance of Reinforced Reactive Powder Concrete Beam-Column Joints under Cyclic Loads
}

\author{
Wenzhong Zheng $\mathbb{D},{ }^{1}$ Dehong Wang $\mathbb{D},{ }^{1,2}$ and Yanzhong Ju' \\ ${ }^{1}$ Key Lab of Structures Dynamic Behavior and Control of the Ministry of Education, Harbin Institute of Technology, \\ Harbin 150090, China \\ ${ }^{2}$ School of Civil Engineering and Architecture, Northeast Electric Power University, Jilin 132012, China \\ Correspondence should be addressed to Dehong Wang; hitwdh@126.com
}

Received 3 August 2017; Revised 14 October 2017; Accepted 20 November 2017; Published 14 March 2018

Academic Editor: Peng Zhang

Copyright (C) 2018 Wenzhong Zheng et al. This is an open access article distributed under the Creative Commons Attribution License, which permits unrestricted use, distribution, and reproduction in any medium, provided the original work is properly cited.

\begin{abstract}
An experimental research was carried out to investigate the seismic performance and shear strength of reactive powder concrete interior beam-column joints subjected to reverse cyclic loads. Four beam-column joint specimens were cast and tested in the investigation. The failure characteristics, deformational properties, ductility, and energy dissipation of reinforced reactive powder concrete interior beam-column joints were analyzed in this paper. The shear strength of joints was calculated according to the GB5001-2010 and ACI 318-14. The results shows that reactive powder concrete beam-column joints have a higher shear-cracking strength and shear carrying capacity and strength degradation and rigidity degradation are not notable. Additionally, the use of RPC for beam-column joints can reduce the congestion of stirrups in joints core. The shear force in the RPC joint is mainly carried by the diagonal strut mechanism; the design expression of ACI 318-14 can be used for calculating the shear strength of RPC joints, which has a safety margin of $22 \% \sim 38 \%$ in this test.
\end{abstract}

\section{Introduction}

Since the 1960s, the performance of reinforced concrete beamcolumn joints has been an active subject in the earthquake resistance of engineering structures, and the field has seen numerous achievements [1-4]. Normal concrete and highstrength concrete have low tension strength and poor toughness, so the ductility of the concrete joints primarily depends on the stirrups; this causes congestion of reinforcing bars in joint and poses difficulty in the placement of concrete $[5,6]$. Besides, due to the brittleness of concrete and the uncoordinated deformation between concrete and bars, the bonding properties of steel and concrete in the joint region will deteriorate under seismic loading. Furthermore, splitting tensile failure and concrete cover spalling failure occur at the interface between concrete and bars. For these reasons, some new design approaches were developed. Ibrahim [6] proposed studs with a head at each end in lieu of conventional closed stirrups in reinforced concrete beam-column joints.
Kotsovou and Harris [7] proposed a method for the seismic design of beam-column joints and proved its validity. Researches have demonstrated that the spacing of stirrups in the joint area can be decreased by using steel fiber-reinforced concrete instead of normal concrete [8-10]. In other words, using fiber concrete or new design approaches can reduce the amount of stirrups, which is convenient for construction. On the other hand, the durability of reinforced concrete structures has become increasingly important. Concrete carbonation and the corrosion of steel bars in reinforced concrete structures can cause premature failure. Reactive powder concrete can be a feasible solution to overcome these problems in reinforced concrete frame joint.

Reactive powder concrete (RPC) is a new cement-based composite with ultrahigh strength and performance. The compressive strength can be as high as $200 \sim 800 \mathrm{MPa}$; the flexural strength can reach $30 \sim 60 \mathrm{MPa}[11,12]$. The frostresistance level of RPC can exceed 690 cycles of freezing and thawing with a low mass-loss rate below $3 \%$. RPC's 
TABLE 1: Specimen parameters.

\begin{tabular}{lccc}
\hline Specimens number & Compressive strength of RPC (MPa) & Stirrups in joint core & Axial compression ratio \\
\hline J-0-0.3 & 112.3 & 0 & 0.3 \\
J-0-0.5 & 104.1 & 0 & 0.5 \\
J-1-0.3 & 105.8 & One 2-leg loop, $6 \mathrm{~mm} \varphi$ & 0.3 \\
$\mathrm{~J}-1-0.5$ & 98.5 & One 2-leg loop, $6 \mathrm{~mm} \varphi$ & 0.5 \\
\hline
\end{tabular}
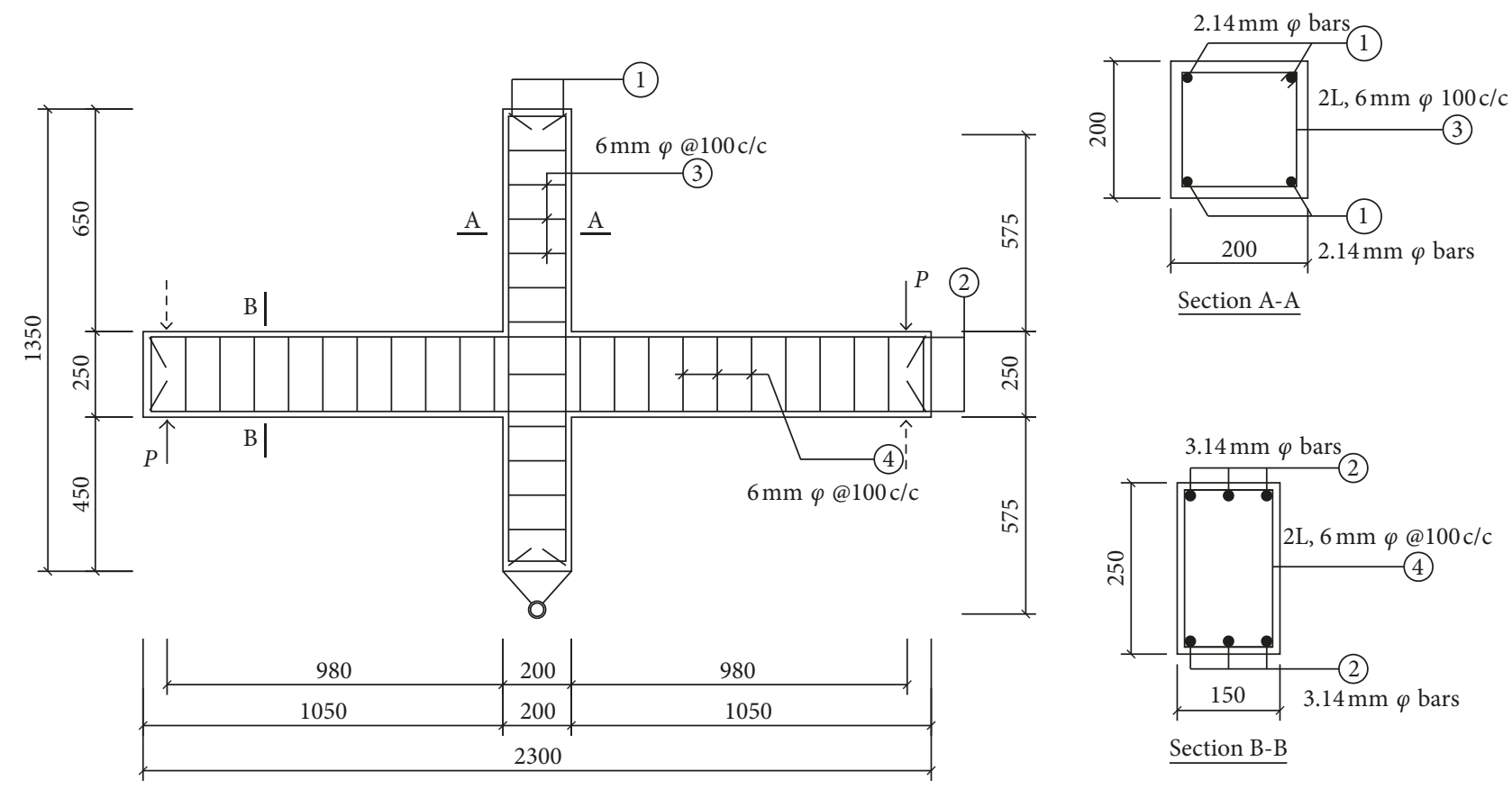

Figure 1: Details of reinforcement.

resistance to carbonation and chloride ion permeability is much higher than other concrete $[13,14]$. Therefore, the mechanical properties and durability of frame structures can be improved by using reactive powder concrete with high strength and durability. Additionally, the section size of the member and the number of stirrups can be reduced.

In recent years, there has been extensive research conducted on RPC in terms of the mix preparation and mechanical properties, and the results indicate that the mechanical properties of RPC are better than NC and HSC $[15,16]$; in addition, studies on the mechanical behavior of the beams and columns has been carried out by Hung and Chueh [17], Malik and Foster [18], and Deng et al. [19]. Wang et al. [20] presented the reported study on the seismic behavior of RPC exterior joints with high-strength bars. Studies have demonstrated that RPC structures differ significantly from normal and high-strength concrete structures because of the difference of performances of RPC materials [21, 22]. This paper, based on the RPC beam-column joints quasistatic test, studies the seismic performance of RPC beam-column joints, investigates the influence of the stirrup ratio and axial compression ratio on the seismic performance of RPC beam-column joints, studies the RPC joint forced destruction mechanism, and provides reference for the seismic design of RPC frame structure.

\section{Experimental Programs}

2.1. Test Specimens. In order to obtain the performance and the shear strength of RPC joint under cyclic loads, the test specimens need to ensure that shear failure in the joint core occurs before beam and column flexural failure. According to the concept "weak connection-strong member, weak beam-strong column," four joint specimens were designed. The specimen design parameters are shown in Table 1. The specimen number consists of the initial letter of joint, the number of stirrups in the core area, and the axial compression ratio. For example, "J-1-0.3" indicates that the joint specimen has one stirrup in the core and an axial compression ratio of 0.3 . The column section size of the specimens is $200 \mathrm{~mm} \times 200 \mathrm{~mm}$, and the beam cross-section size is $150 \mathrm{~mm} \times 250 \mathrm{~mm}$. Specimen size and reinforcement details are shown in Figure 1.

2.2. Material Properties. Table 2 summarizes mixture proportions of RPC produced. The RPC were made using Grade 42.5 ordinary Portland cement; Table 3 shows the chemical compositions and physical properties of the cement. Silica fume has a particle size of less than $2 \mu \mathrm{m}$, a density of $2.214 \mathrm{~kg} / \mathrm{m}^{3}$, and an $\mathrm{SiO}_{2}$ content of $82.2 \%$. The aggregate is quartz sand with diameter range of $0-2.5 \mathrm{~mm}$. 
TABLE 2: Mixture proportions of RPC.

\begin{tabular}{|c|c|c|c|c|c|c|c|}
\hline Material & Cement & Silica fume & Quartz sand & Steel fiber & Superplasticizer & Water from SP & Water \\
\hline Quantity $\left(\mathrm{kg} / \mathrm{m}^{3}\right)$ & 756.7 & 227.0 & 1278.1 & 105.8 & 20.4 & 47.5 & 168.9 \\
\hline
\end{tabular}

TABle 3: The chemical compositions and physical properties and of the cement.

\begin{tabular}{ccccccccccccc}
\hline \multicolumn{10}{c}{ Chemical compositions (\%) } \\
\hline $\mathrm{SiO}_{2}$ & $\mathrm{Fe}_{2} \mathrm{O}_{3}$ & $\mathrm{Al}_{2} \mathrm{O}_{3}$ & $\mathrm{CaO}$ & $\mathrm{MgO}$ & $\mathrm{SO}_{3}$ & $\mathrm{R}_{2} \mathrm{O}$ & LOI & Density $\left(\mathrm{g} / \mathrm{cm}^{3}\right)$ & $f_{\text {ct,f,3 }}(\mathrm{MPa})$ & $f_{\text {ct,f, } 28}(\mathrm{MPa})$ & $f_{\text {ct, } \mathrm{f}, 3}(\mathrm{MPa})$ & $f_{\text {ct,f, } 28}(\mathrm{MPa})$ \\
21.04 & 2.93 & 4.66 & 65.97 & 1.82 & 2.52 & 0.90 & 2.11 & 3.18 & 5.17 & 9.62 & 29.2 & 61.5 \\
\hline
\end{tabular}

LOI, loss on ignition.

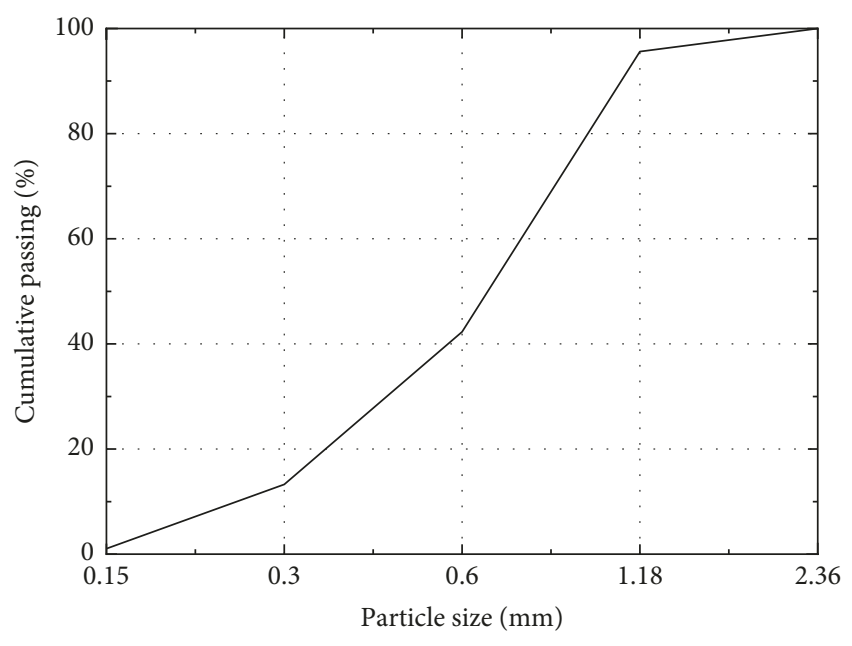

FIGURE 2: The particle size distribution curve of quartz sand.

Figure 2 shows the particle size distribution curve of quartz sand. The steel fiber volume content is $1.3 \%$. The compressive strength of RPC is shown in Table 1. The longitudinal reinforcement bars of the specimens are HRB400 hot rolled ribbed steel bars (diameter of $14 \mathrm{~mm}$ ). The stirrups are HPB300 reinforced (diameter of $6 \mathrm{~mm}$ ). Table 4 shows the measured mechanical properties of the reinforcing bars.

2.3. Test Apparatus and Loading Procedure. Figure 3 shows the test setup and instrumentation. For all specimens, an axial load was applied to the column and was maintained constant throughout the test. An antisymmetric concentrated force (or displacement) was applied to the free end of the beam. The column end axial force was applied by a hydraulic jack, and a $2000 \mathrm{kN}$ load sensor was used to measure the value. The beam tip cyclic load was applied by MTS electrohydraulic servo actuator. The force and displacement of beam tips were recorded by MTS actuator.

The shear deformation of the joints was measured by two displacement sensors placed in the main diagonal directions, as shown in Figure 3(b). The shear deformation of the joints was obtained by converting the displacement measured by displacement sensors. The rotating plastic hinge region is represented by the average cross-sectional curvature. The apparatus used for measuring the curvature of the beams is shown in Figure 3(b). The strains in longitudinal reinforcement bar and stirrups in joint core were monitored by electrical resistance strain gauges.

To eliminate unevenness of axial load, $30 \%$ of the axial force is applied initially, then, it is unloaded to 0 , and finally, the load is applied to the design value and is maintained constant throughout the test. The axial loading history is shown in Figure 4(a). The cyclic loading procedure of the beam tip for all specimens consists of two phases. It begins with a load-controlled phase followed by a displacementcontrolled one. During the force-controlled phase, a load of $5 \mathrm{kN}$ is applied with differential loading step by step, and every load cycle occurs once. When the specimen reaches cracking or at steel bar yield, the process is switched to displacement control, and at this time, the displacement is denoted as $\Delta_{\mathrm{y}}$. The displacement is incremented by $\Delta_{\mathrm{y}}$, and each displacement level cycle occurs three times. The test stops when the load reduces to $85 \%$ of the peak load. The loading history of the beam tip is shown in Figure 4(b), and the left and right tips of the beam simultaneously load in reverse.

\section{Test Results and Discussion}

3.1. Failure Characteristics of RPC Beam-Column Joints. The failure model of all four of the specimens was shear failure, and all of the specimens had a similar failure process, which can be divided into three stages: the initial crack, penetrating crack, and failure. In the initial-crack stage, when the load reached about $55 \%$ of the peak load, the first diagonal crack was observed in a diagonal direction of the joint area. At this time, the stirrup strain was small (about $600 \times 10^{-6} \sim 800 \times 10^{-6}$ ). In the reverse loading phase, the first diagonal crack was observed in another diagonal direction. For the moment, the shear in the joint was mainly afforded by the RPC. For the specimens, the crack load of the joint core area was very close; the crack load of specimen J-0-0.3 and J-0-0.5 were $25 \mathrm{kN}$, whereas the other two specimens had crack loads of $30 \mathrm{kN}$. The shear deformation of four specimens at crack load was less than $0.001 \mathrm{rad}$.

With an increased load and number of cycles, the initial crack along the diagonal direction continued to extend, and the specimens gradually entered into the penetrating crack stage. At the first $2 \Delta_{\mathrm{y}}$ cycle, the original diagonal cracks along the diagonal direction extended to the corner, forming the main perforation cracks. In the vicinity of the diagonal, there were three or four small 
TABLE 4: Mechanical properties of reinforcing bars.

\begin{tabular}{lccccc}
\hline Type of reinforcement & Application & Diameter $(\mathrm{mm})$ & Yield strength $(\mathrm{MPa})$ & Ultimate strength $(\mathrm{MPa})$ & $\mathrm{Modulus}$ of elastic $(\mathrm{GPa})$ \\
\hline HRB400 & Longitudinal bars & 14 & 423.40 & 632.40 & 200 \\
HPB300 & Transverse stirrup & 6 & 353.56 & 398.30 & 210 \\
\hline
\end{tabular}

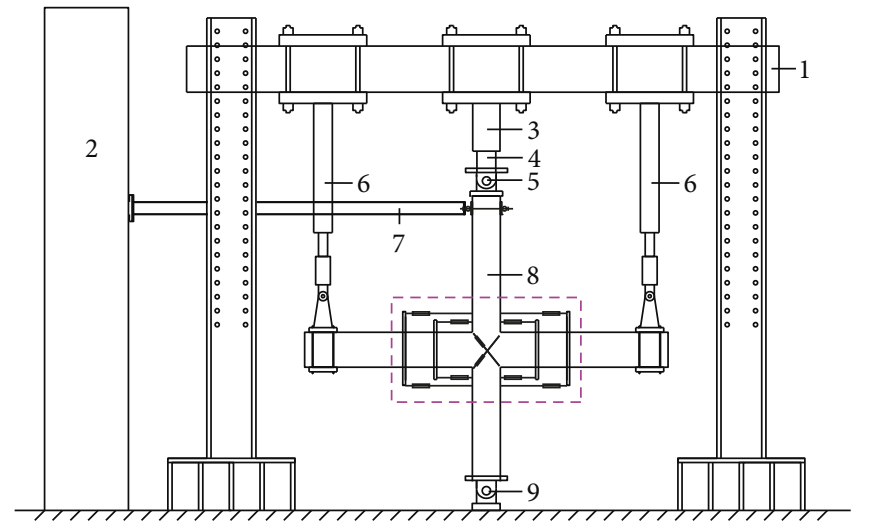

(a)

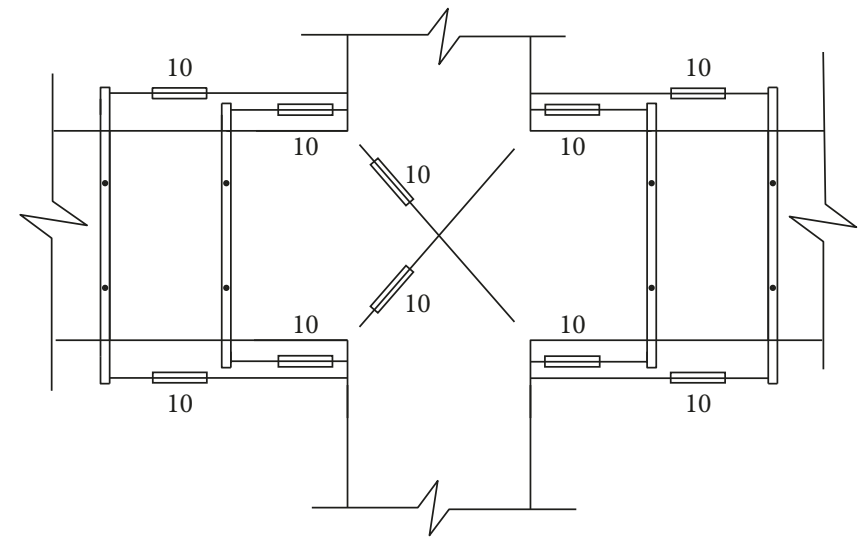

(b)

Figure 3: Loading device of the test. (a) Schematic diagram of load test. (b) Displacement sensor arrangement. (1) Rigid frame; (2) reactingforce wall; (3) hydraulic jack; (4) load sensor; (5) hinge; (6) MTS actuators; (7) spreader beam; (8) specimen; (9) hinge base; (10) displacement sensor.

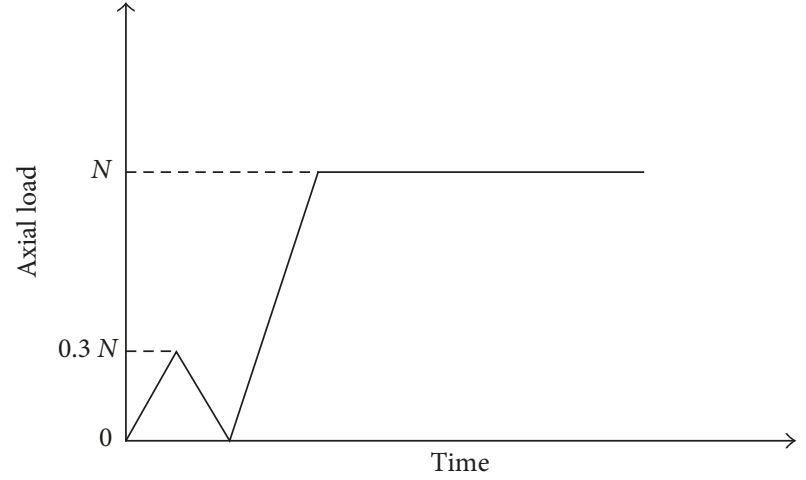

(a)

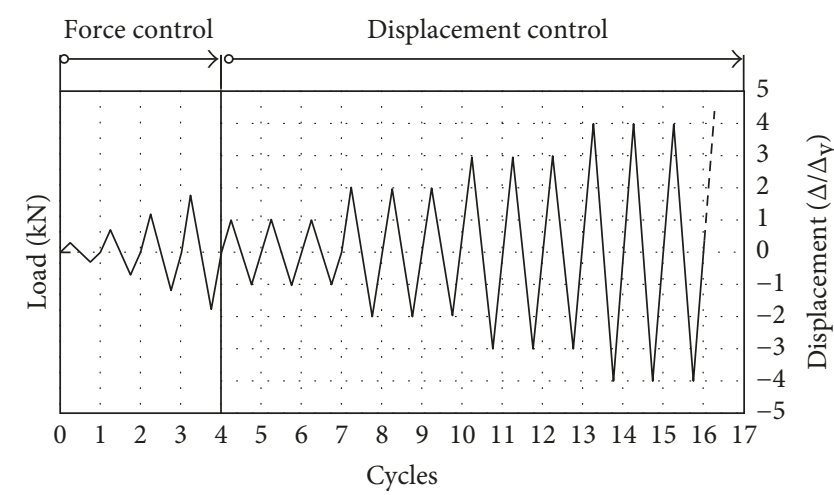

(b)

FIGURE 4: The schematic view of loading history. (a) Loading procedure of column end. (b) Loading procedure of beam tip.

diagonal cracks that paralleled the diagonal direction. At this time, the maximum crack width of the joint area was approximately $0.3 \mathrm{~mm}$, and the joint core still had good shear resistance; the average shear deformation of the joint was $2.64 \times 10^{-3} \mathrm{rad}$. When the $2 \Delta_{\mathrm{y}}$ cycle continued for the second and third cycles, the widening of the main crack accelerated, and a larger number of diagonal cracks with small widths appeared around the main crack. When the first $3 \Delta_{y}$ cycle ended, the width of the main diagonal crack in the joint core area significantly increased, and the maximum width was about $1.5 \mathrm{~mm}$.

At the failure stage, the width of the main diagonal crack in the joint continued to increase, the stirrup strain in joint core rapidly increased and eventually reached yield, and the average shear deformation of the joint multiplied. Parts of steel fibers were pulled out from the matrix, and part of the RPC near the main crack started to peel. At the loading ends, large cracks might appear, but specimens remained as an integral. The specimen failure mode is shown in Figure 5. RPC has a high tensile strength and tension strain, which can delay joint core cracking as well as delay the tensile yield of stirrups in the joint core. In addition, the high tensile strength of RPC can reduce the speed at which cracks develop; thus, the compressive strength can be sufficient to play and improve the carrying capacity of joints.

3.2. Load-Deformation Hysteresis Curve. The load-displacement $(P-\Delta)$ curve of beam tip is a comprehensive reflection of joint specimens under cyclic loading, which can reflect 


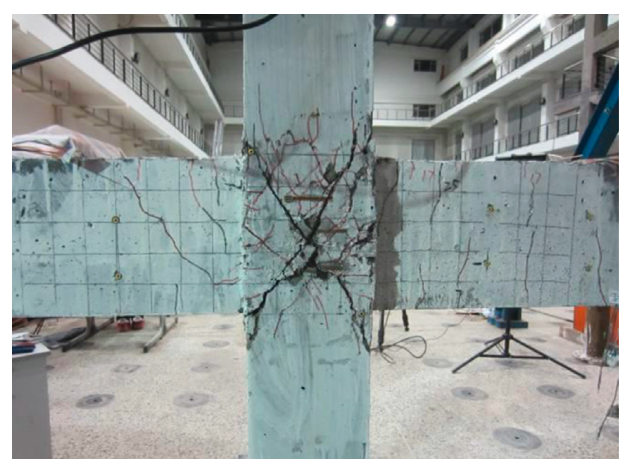

(a)

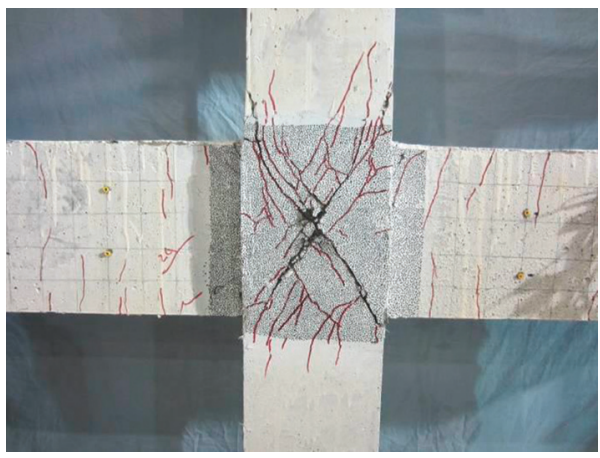

(c)

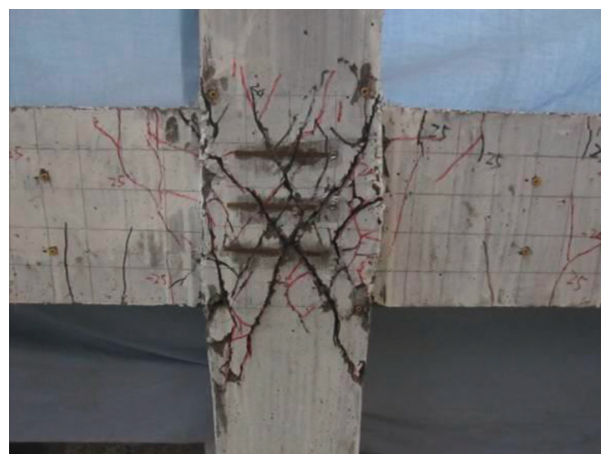

(b)

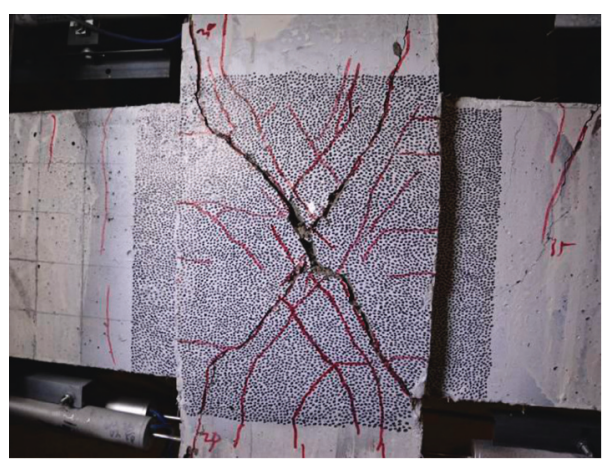

(d)

FIgURE 5: Failure mode of joints. (a) Specimen J-0-0.3. (b) Specimen J-0-0.5. (c) Specimen J-1-0.3. (d) Specimen J-1-0.5.

joints' seismic performance indicators such as bearing capacity, ductility, energy dissipation, the strength reduction, rigidity degradation, and so on. Figure 6 shows the load-displacement hysteretic loop of four test specimens, where $\mathrm{L}$ represents the left beam and $\mathrm{R}$ represents the right beam. The hysteresis curve of reinforced RPC beamcolumn joint has the following characteristics:

(1) In the early stage, the hysteresis loops were narrow strips, and the area surrounded by hysteresis loops was smaller. The slope decline of hysteresis curve was not obvious.

(2) In the stage of displacement control, during $1 \Delta_{y}$ displacement stage, strength of joints almost did not reduce. When the loading displacement increased to $2 \Delta_{\mathrm{y}}$, the load of beam end continued to increase, and specimens J-0-0.3, J-1-0.3, and J-1-0.5 reached their maximum carrying capacity, respectively, at the first cycle of $2 \Delta_{\mathrm{y}}$. During the second and third cycles of $2 \Delta_{y}$, the strength declined slightly, the decline were no more than $5 \%$. During the first cycle of $3 \Delta_{y}$, the strength of specimen J-0-0.5 reached its maximum while the strength of other specimens were close to the strength at $2 \Delta_{\mathrm{y}}$ first cycle. With the increase of the cycles, the capacity of specimens began to decline significantly. In this case, the load-displacement hysteresis curve became " $\mathrm{S}$ " shape, and the area surrounded by the hysteresis loop also increased rapidly; it indicated that the energy dissipation of specimen increased.
3.3. Shear Force-Deformation Angle Hysteresis Loops. The joint shear deformation angle of joint can be calculated by

$$
\gamma=\frac{\sqrt{a^{2}+b^{2}}}{2 a b}\left(\Delta_{1}+\Delta_{2}+\Delta_{3}+\Delta_{4}\right)
$$

where $\gamma$ represents the average value of joint shear deformation angle; $a$ and $b$ represent the horizontal and vertical distances between the end points of the diagonal; and $\left(\Delta_{1}+\Delta_{2}\right)$ and $\left(\Delta_{3}+\Delta_{4}\right)$ are the changes in length of diagonals (Figure 7).

According to the China code, the shear strength $\left(V_{j}\right)$ of reinforced RPC joints can be calculated by the equation [23]

$$
V_{j}=\frac{\sum M_{b}}{h_{b 0}-a_{s}^{\prime}}\left(1-\frac{h_{b 0}-a_{s}^{\prime}}{H_{c}-h_{b}}\right),
$$

where $\sum M_{b}$ represents the total bending moment of beam adjoining joint core, $\sum M_{b}=P_{1} L_{1}+P_{2} L_{2} ; H_{c}$ is total depth of column; $h_{b 0}$ is effective depth of beam, $h_{b 0}=h_{b}-a_{s} ; h_{b}$ is depth of beam; and $a_{s}$ and $a_{s}^{\prime}$ are the distance from the resultant force center of tensile and compressive reinforcement to corresponding edge.

Figure 8 shows the shear force-deformation angle $\left(V_{j^{-}} \gamma\right)$ hysteretic curves of the four specimens. It can be observed from Figure 8 that the slope rates of the loading curve were basically consistent with unloading curve during load control stage; this indicates that the joint is about in elastic state before cracking in joint core. During the $1 \Delta_{\mathrm{y}}$ 
Story drift ratio (\%)

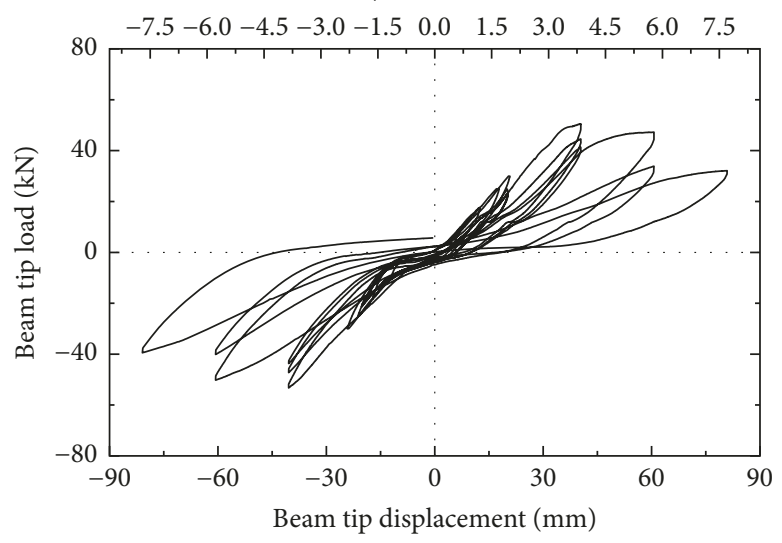

- J-0-0.3-L

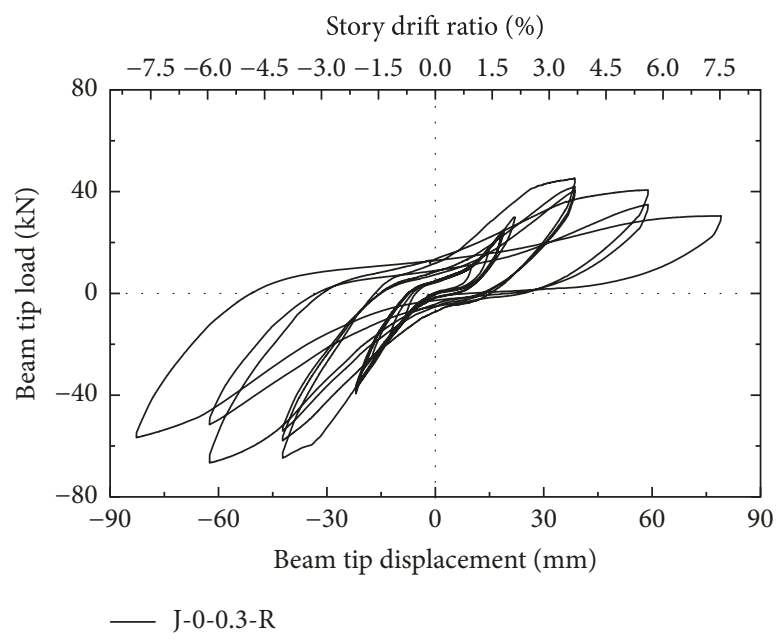

(a)

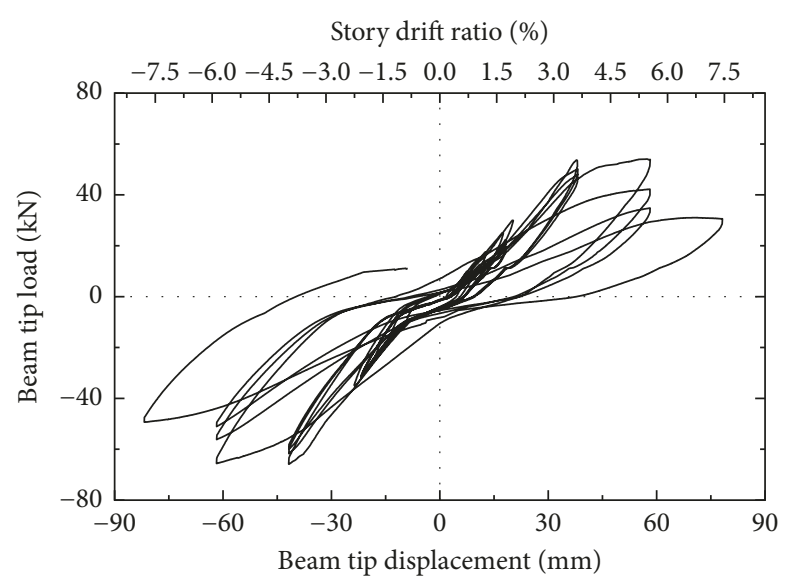

- J-0-0.5-L

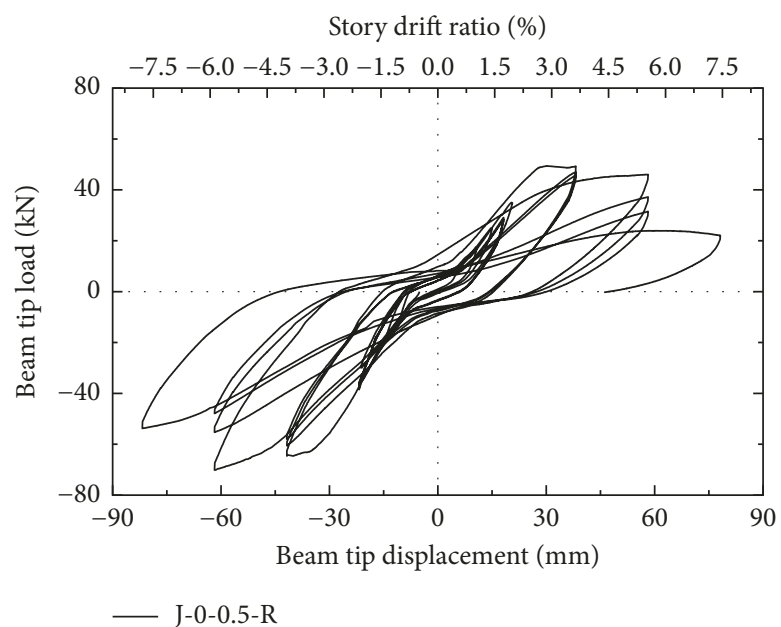

(b)
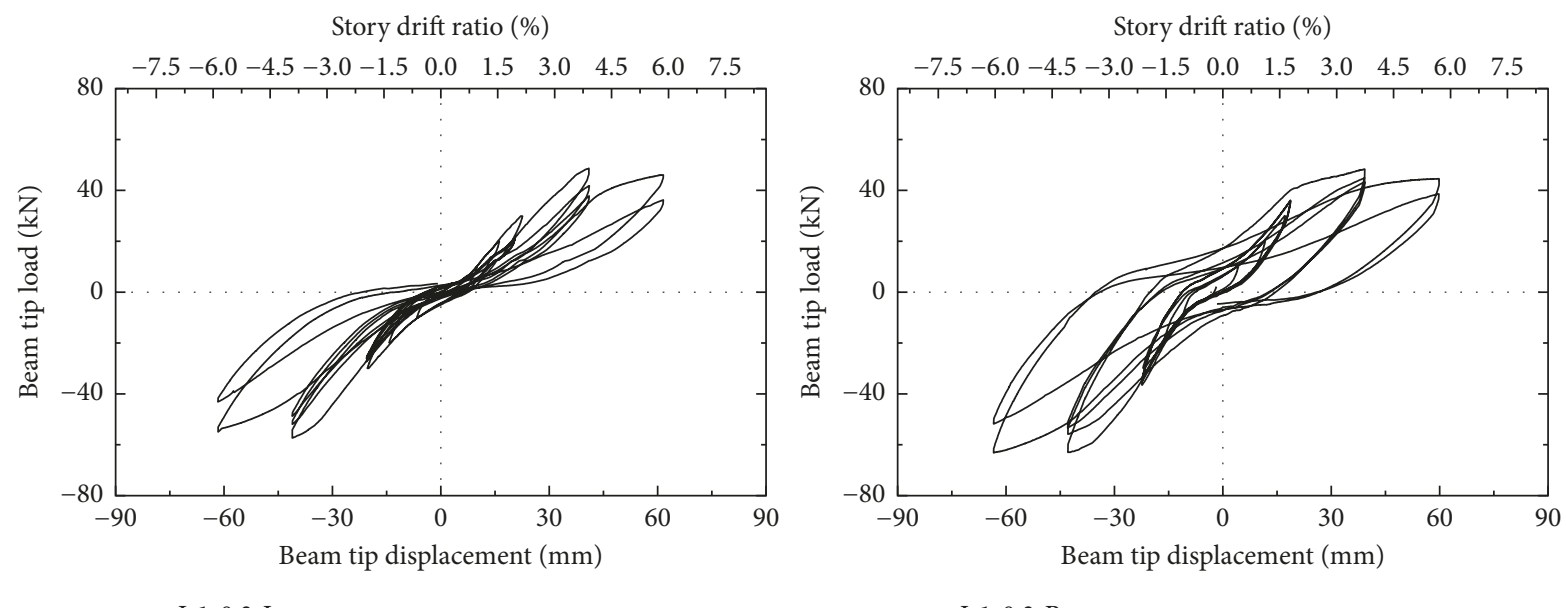

- J-1-0.3-L

(c)

FIgUre 6: Continued. 

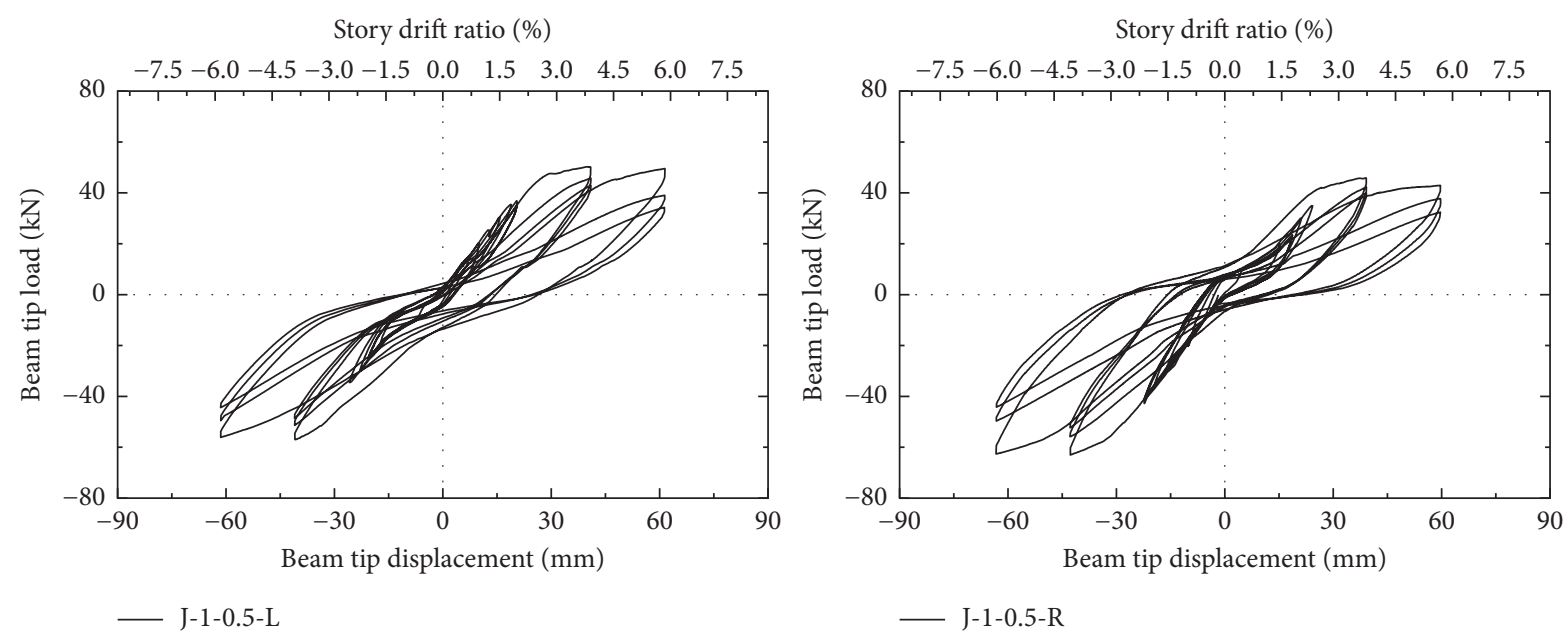

(d)

Figure 6: Hysteresis curve of joints. (a) Specimen J-0-0.3. (b) Specimen J-0-0.5. (c) Specimen J-1-0.3. (d) Specimen J-1-0.5.

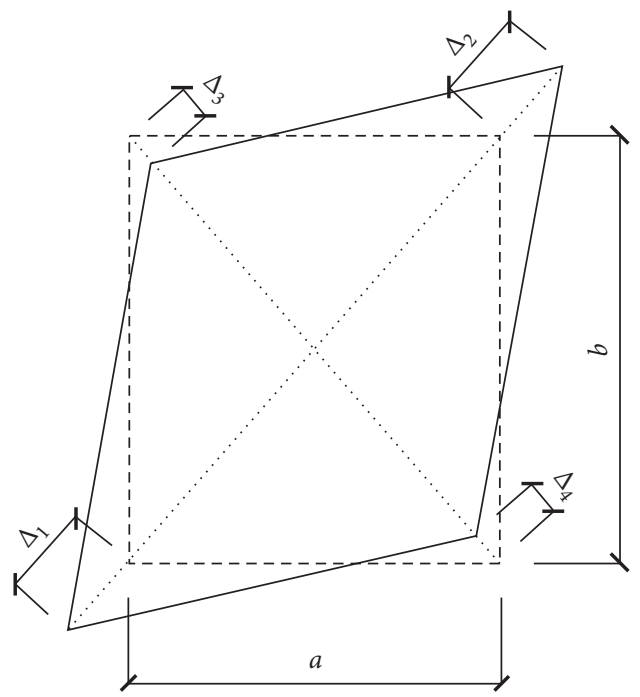

Figure 7: Calculation of the joint shear deformation angle $\gamma$.

displacement stage, the shear deformation value of joints was very small. During the $2 \Delta_{\mathrm{y}}$ displacement stage, four joint specimens all reached the maximum shear carrying capacities at the first $2 \Delta_{\mathrm{y}}$ cycle; then the strength reduction and stiffness degradation began to appear at the second and third cycles of $2 \Delta_{\mathrm{y}}$ displacement. At the first $3 \Delta_{\mathrm{y}}$ cycle, the shear deformation angles significantly increase, but the shear load of specimens is close to the value at the first $2 \Delta_{\mathrm{y}}$ cycle. This indicates that RPC beam-column joint has a good ability of deformation and toughness. At the second and third cycles of $3 \Delta_{\mathrm{y}}$ displacement, the shear deformation angles of specimens continue to increase, and strengths drop till failure.

3.4. Strength Degradation. The strength of the joint specimens decreased at the same displacement level with an increasing number of cycles. The strength degradation coefficient $\left(\lambda_{j}\right)$ presented in the Chinese code [24] is used to illustrate the degradation. $\lambda_{j}$ can be calculated by

$$
\lambda_{j}=\frac{P_{j}^{i}}{P_{j}^{1}}
$$

where $P_{j}^{1}$ is the peak force of the first cycle at the displacement level of $j\left(j=\Delta / \Delta_{\mathrm{y}}\right)$, and $P_{j}^{i}$ is the peak force of the second or third cycle $(i=2$ or 3$)$ at the same displacement level of $j\left(j=\Delta / \Delta_{\mathrm{y}}\right)$.

The $\lambda_{j}$ versus $\Delta / \Delta_{\mathrm{y}}$ curve for the reinforced RPC beamcolumn joints is shown in Figure 9. It can be seen that, the coefficient $\lambda_{j}$ of the specimens decreases as the level of displacement increases; $\lambda_{j}$ decreases as cycles increases at the same displacement level. $\lambda_{j}$ increases as the axial compression ratio increases.

3.5. Rigidity Degradation. The rigidity coefficient $K_{j}$ is defined as the slope of the line joining the upward and downward peak loads of one loop of the load-displacement hysteresis loops. Figure 10 shows the looped rigidity coefficient $\left(K_{j}\right)$ versus displacement $\left(\Delta / \Delta_{\mathrm{y}}\right)$ relationship of RPC concrete beam-column joints. For each displacement level, the rigidity coefficient was calculated using the peak load values of the first cycle.

According to Figure 10, rigidity degradation can be found in all specimens, and the rigidity coefficient of specimen changes marginally from $1 \Delta_{\mathrm{y}}$ to $2 \Delta_{\mathrm{y}}$, but rigidity coefficient decreased significantly when the displacement of beam tip exceeds $2 \Delta_{\mathrm{y}}$. This can be contributed to the fact that cracks were developing quickly and failures started to occur at $3 \Delta_{\mathrm{y}}$.

3.6. Ductility of Joints. Ductility is an important index for the seismic design of structures and is characterized by a ductility factor. According to different deformation types, the ductility 


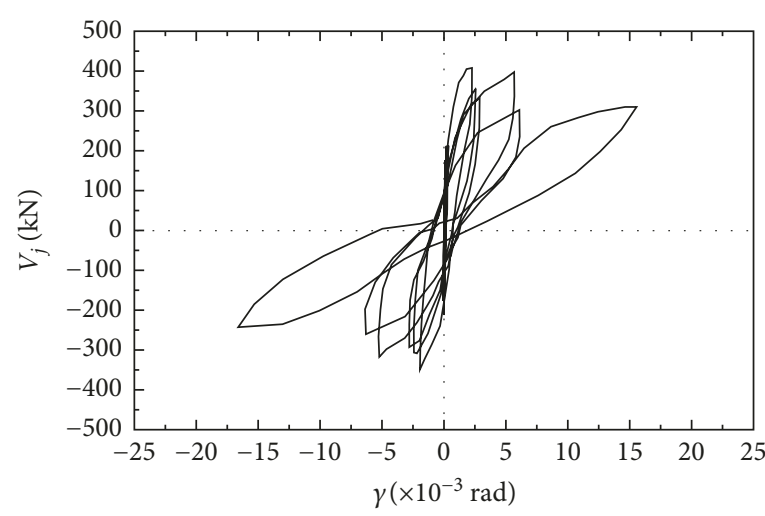

$-\mathrm{J}-0-0.3$

(a)

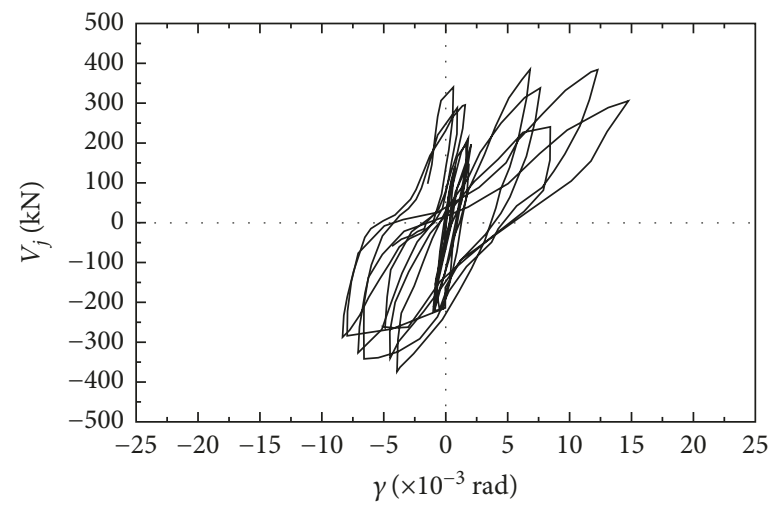

$-\mathrm{J}-1-0.3$

(c)

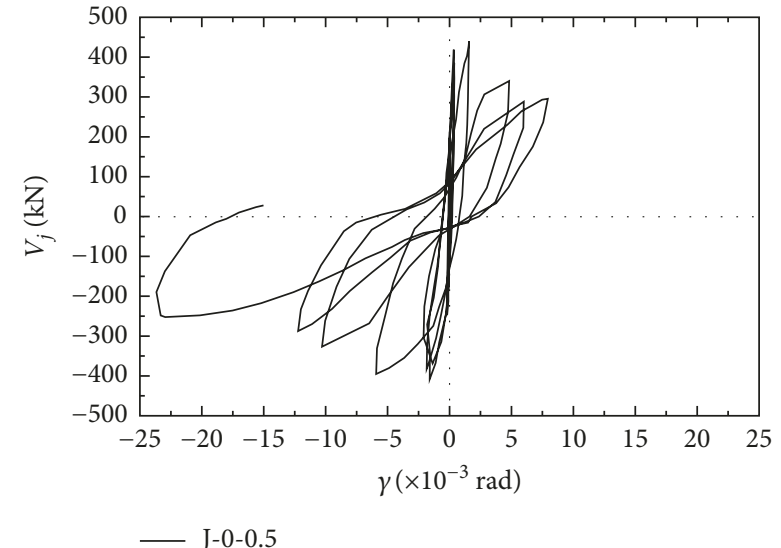

(b)

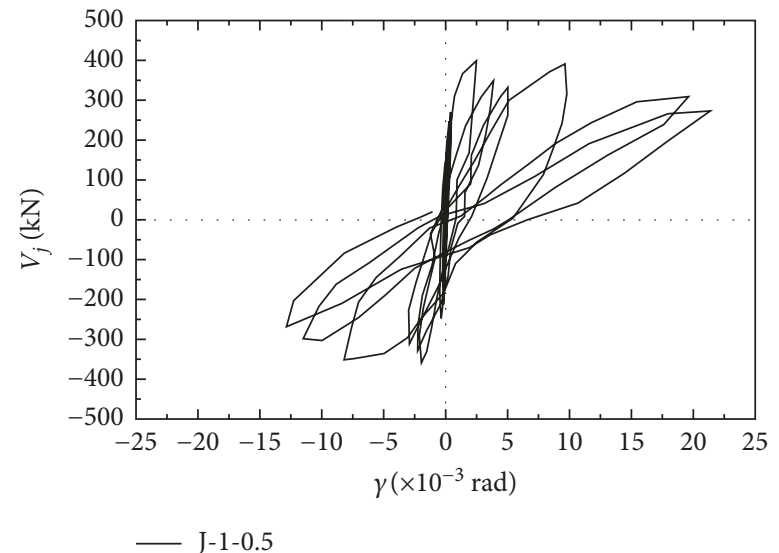

(d)

FIgURE 8: Shear force versus shear deformation angle of joints core. (a) Specimen J-0-0.3. (b) Specimen J-0-0.5. (c) Specimen J-1-0.3. (d) Specimen J-1-0.5.

factor can be divided into three types: a curvature ductility factor, displacement ductility factor, and rotation ductility factor. In this paper, the displacement ductility factor $\mu$ is used to measure the ductility of the specimens. It is defined as $\mu=\Delta_{u} / \Delta_{\text {ye }}$, where $\Delta_{u}$ is the ultimate displacement when the specimen destructs, which is the beam tip corresponding to the displacement when the load reaches $85 \%$ of the maximum load. The corresponding load to $\Delta_{u}$ is the ultimate load $P_{u}$. Yield displacement $\Delta_{\mathrm{ye}}$ can be calculated by the Park method [25], and the corresponding load to $\Delta_{\mathrm{ye}}$ is the yield load $P_{\text {ye. }}$.

Table 5 shows the main feature points' test results and displacement ductility factors of each specimen. The first crack load increased with increase of stirrup in joint and axial load of column, which may be due to the increase in confined effect from stirrup and compression from column. The ductility factors of four specimens are small, ranging from about 1.63 to 2.29 . This is because the failure mode of all four specimens is shear failure in joint core. Specimen J-10.3 and specimen $\mathrm{J}-1-0.5$, which configure only a stirrup in the joint core, do not manifest a higher ductility than specimens without stirrup in the joint core. This phenomenon can contribute to fewer stirrups being configured by specimens. The stirrups yielded before the specimens reached their maximum carrying capacity, so fewer stirrups in the joint area have no effect on the ductility of the specimens. Furthermore, this also indicates that RPC has a good shear ductility, which shows an excellent ductility characteristic under shear load, and the feature has less dependence upon the restraint of the stirrups. It can reduce the consumption of stirrup to use RPC instead of normal concrete in the joint area, and it is easy for construction.

3.7. Energy Dissipation. Energy dissipation is an important indicator of seismic performance. The enclosed area formed by the load-displacement hysteresis loops can be used to characterize the size of the energy dissipation.

Figure 11 shows the hysteretic energy dissipation curve of different RPC beam-column joints under different loading grades. As can be seen from the figure, specimens in the small deformation stage have less energy dissipation. When the load displacement was $1 \Delta_{\mathrm{y}}$ (about $2.1 \% \mathrm{drift}$ ), the energy dissipation capacities of the four specimens were $516.2 \mathrm{kN} \cdot \mathrm{mm}$, $554.6 \mathrm{kN} \cdot \mathrm{mm}, 551.6 \mathrm{kN} \cdot \mathrm{mm}$, and $528.9 \mathrm{kN} \cdot \mathrm{mm}$. When the load displacement was $2 \Delta_{\mathrm{y}}$ (about $4.3 \% \mathrm{drift}$ ), the energy 


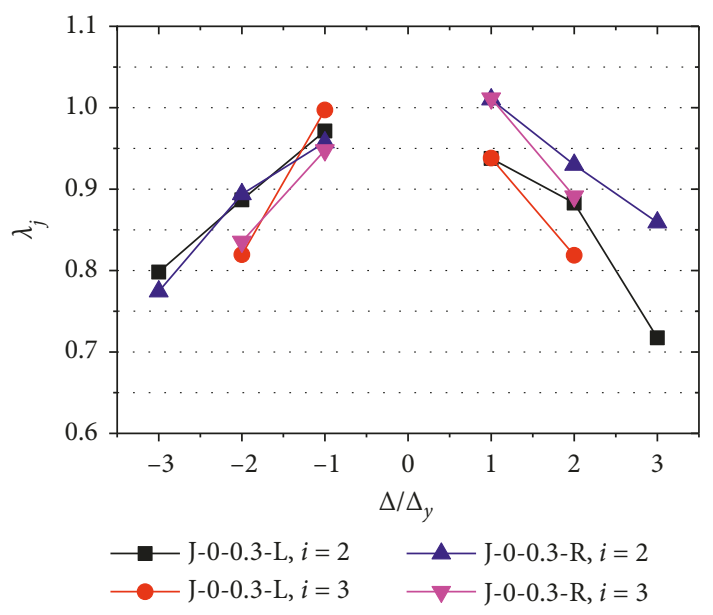

(a)

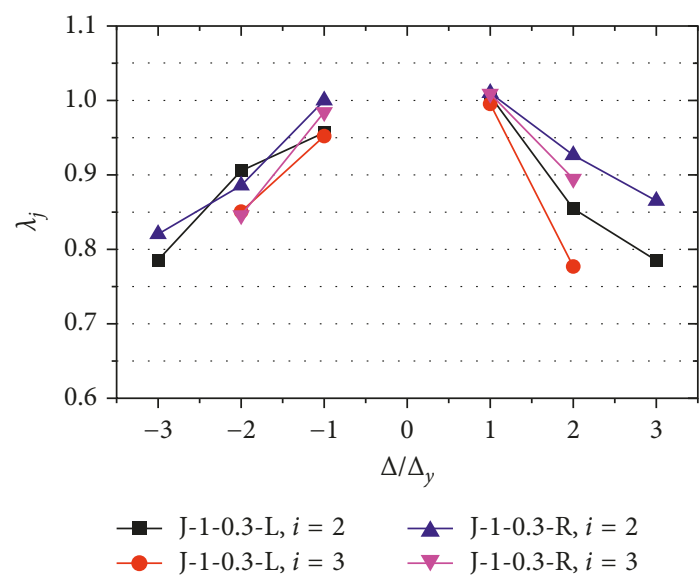

(c)

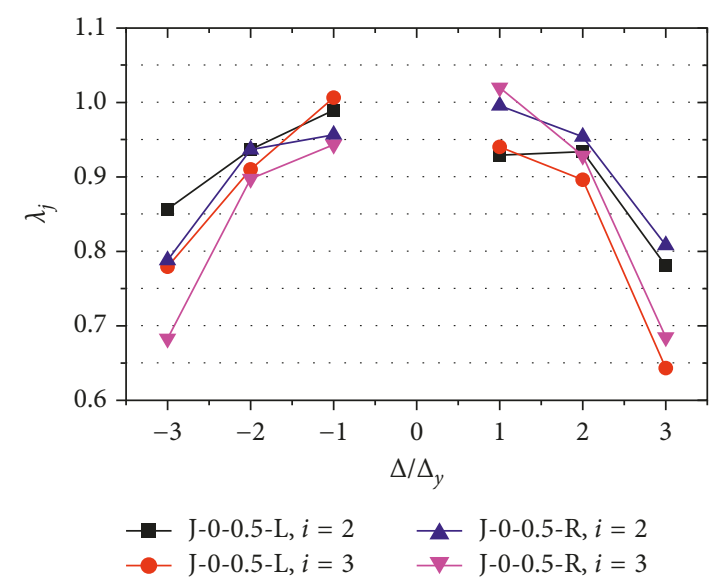

(b)

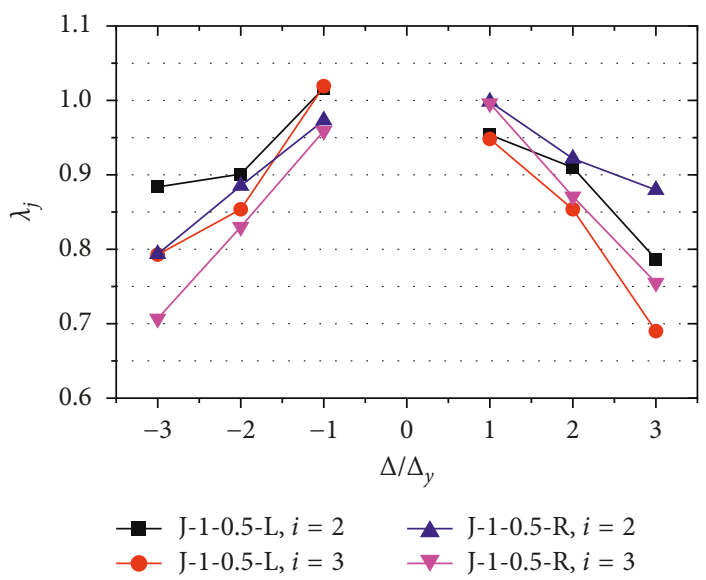

(d)

Figure 9: $\lambda_{j}$ versus $\Delta / \Delta_{\mathrm{y}}$ relationship. (a) Specimen J-0-0.3. (b) Specimen J-0-0.5. (c) Specimen J-1-0.3. (d) Specimen J-1-0.5.

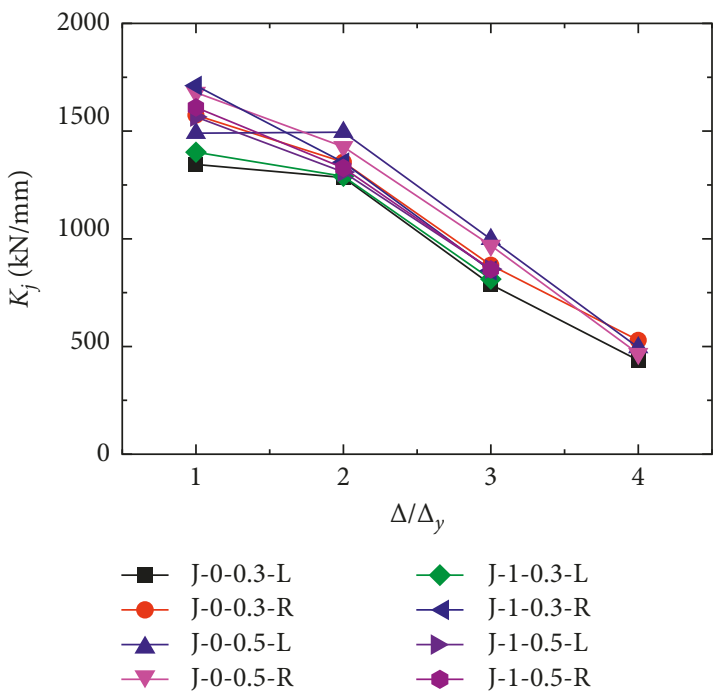

FIGURE 10: $K_{j}$ versus $\Delta / \Delta_{\mathrm{y}}$ relations.

dissipation capacities of the four specimens were $2374.5 \mathrm{kN} \cdot \mathrm{mm}$, $2837.1 \mathrm{kN} \cdot \mathrm{mm}, 2640.1 \mathrm{kN} \cdot \mathrm{mm}$, and $2790.5 \mathrm{kN} \cdot \mathrm{mm}$. When the load displacement was $3 \Delta_{\mathrm{y}}$ (about $6.4 \%$ drift), the energy dissipation capacities of the four specimens were $5058.2 \mathrm{kN} \cdot \mathrm{mm}$, $5956.6 \mathrm{kN} \cdot \mathrm{mm}, 5071.6 \mathrm{kN} \cdot \mathrm{mm}$, and $5413.5 \mathrm{kN} \cdot \mathrm{mm}$.

The energy dissipation of joints increases with increasing axial compression. Under the same axial compression ratio, the stirrup of the joint core can improve the energy consumption slightly. An increase in RPC shear strength can improve the energy dissipation capacity to a certain degree. After stirrups yield, energy dissipations of the four specimens are close. The reason could be the axial compression, and the existence of stirrups can suppress diagonal crack of joint core developing. In addition, the axial compression also improves the friction resistance between longitudinal reinforcements and RPC in the joint core.

\section{Shear Strength of RPC Beam-Column Joints}

Based on test results, the shear strength of reinforced RPC joints can be calculated by (2). Table 6 shows the shear strength of four specimens, in order to study the influence of axial compression ratio and stirrup ratio in joints core on shear strength. Considering the differences in RPC strength of different specimens, shear-compression ratio $\left(V_{j} / f_{c} b_{j} h_{j}\right)$ was defined to analyze shear strength of unit 
TABLE 5: Main feature points' test results and displacement ductility factor.

\begin{tabular}{|c|c|c|c|c|c|c|c|c|c|}
\hline $\begin{array}{l}\text { Specimen } \\
\text { numbers }\end{array}$ & Direction & $\begin{array}{l}\text { First } \\
\text { crack } \\
\text { load } \\
(\mathrm{kN})\end{array}$ & $\begin{array}{c}\text { Displacement } \\
\Delta_{\text {ye }} \text { at yield load } \\
(\mathrm{mm})\end{array}$ & $\begin{array}{l}\text { Yield } \\
\text { load, } P_{\text {ye }} \\
(\mathrm{kN})\end{array}$ & $\begin{array}{c}\text { Displacement } \\
\Delta_{\max } \text { at peak } \\
\text { load }(\mathrm{mm})\end{array}$ & $\begin{array}{l}\text { Peak } \\
\text { load, } \\
P_{\max } \\
(\mathrm{kN})\end{array}$ & $\begin{array}{l}\text { Displacement } \Delta_{u} \\
\text { at ultimate load } \\
(\mathrm{mm})\end{array}$ & $\begin{array}{l}\text { Ultimate } \\
\text { load, } P_{u} \\
\quad(\mathrm{kN})\end{array}$ & $\begin{array}{c}\text { Displacement } \\
\text { ductility } \\
\text { factor } \mu\end{array}$ \\
\hline \multirow{3}{*}{$J-0-0.3-\mathrm{L}$} & Downward & 25 & 34.73 & 44.69 & 40.46 & 50.5 & 64.75 & 42.93 & 1.86 \\
\hline & Upward & 30 & 35.76 & 48.43 & 40.46 & 53.3 & 69.07 & 45.31 & 1.93 \\
\hline & Average & 27.5 & 35.245 & 46.56 & 40.46 & 51.9 & 66.91 & 44.12 & 1.90 \\
\hline \multirow{3}{*}{$J-0-0.3-R$} & Downward & 30 & 28.38 & 41.16 & 40.46 & 45.4 & 63.26 & 38.59 & 2.23 \\
\hline & Upward & 25 & 33.93 & 60.64 & 60.69 & 66.7 & 79.51 & 56.7 & 2.34 \\
\hline & Average & 27.5 & 31.155 & 50.9 & 50.575 & 56.05 & 71.385 & 47.645 & 2.29 \\
\hline \multirow{3}{*}{$J-0-0.5-\mathrm{L}$} & Downward & 25 & 38.98 & 49.02 & 60 & 54.7 & 66.49 & 46.5 & 1.71 \\
\hline & Upward & 30 & 35.9 & 61.92 & 40 & 66 & 71.3 & 56.1 & 1.99 \\
\hline & Average & 27.5 & 37.44 & 55.47 & 50 & 60.35 & 68.895 & 51.3 & 1.85 \\
\hline \multirow{3}{*}{$\mathrm{J}-0-0.5-\mathrm{R}$} & Downward & 30 & 29.77 & 48.74 & 40 & 49.5 & 63.25 & 42.08 & 2.12 \\
\hline & Upward & 25 & 33.69 & 62.96 & 60 & 70.2 & 72.84 & 59.67 & 2.16 \\
\hline & Average & 27.5 & 31.73 & 55.85 & 50 & 59.85 & 68.045 & 50.875 & 2.14 \\
\hline \multirow{3}{*}{$J-1-0.3-\mathrm{L}$} & Downward & 30 & 36.96 & 44.48 & 41.1 & 48.7 & 61.65 & 45.9 & 1.67 \\
\hline & Upward & 30 & 38.57 & 55.43 & 41.1 & 57.4 & 61.65 & 48.8 & 1.60 \\
\hline & Average & 30 & 37.765 & 49.955 & 41.1 & 53.05 & 61.65 & 47.35 & 1.63 \\
\hline \multirow{3}{*}{$J-1-0.3-R$} & Downward & 30 & 30.54 & 41.69 & 41.1 & 48.4 & 61.65 & 44.59 & 2.02 \\
\hline & Upward & 30 & 34.27 & 59.16 & 41.1 & 63 & 61.65 & 53.55 & 1.80 \\
\hline & Average & 30 & 32.405 & 50.425 & 41.1 & 55.7 & 61.65 & 49.07 & 1.91 \\
\hline \multirow{3}{*}{$\mathrm{J}-1-0.5-\mathrm{L}$} & Downward & 30 & 26.3 & 34.84 & 41 & 49.9 & 61.5 & 49.16 & 2.34 \\
\hline & Upward & 35 & 34.13 & 59.05 & 41 & 57.5 & 61.5 & 56.5 & 1.80 \\
\hline & Average & 32.5 & 30.215 & 46.945 & 41 & 53.7 & 61.5 & 52.83 & 2.07 \\
\hline \multirow{3}{*}{$J-1-0.5-R$} & Downward & 35 & 35.56 & 45.75 & 41 & 46 & 61.5 & 43.72 & 1.73 \\
\hline & Upward & 30 & 38.52 & 58.95 & 41 & 63.1 & 61.5 & 49.2 & 1.60 \\
\hline & Average & 32.5 & 37.04 & 52.35 & 41 & 54.55 & 61.5 & 46.46 & 1.66 \\
\hline
\end{tabular}

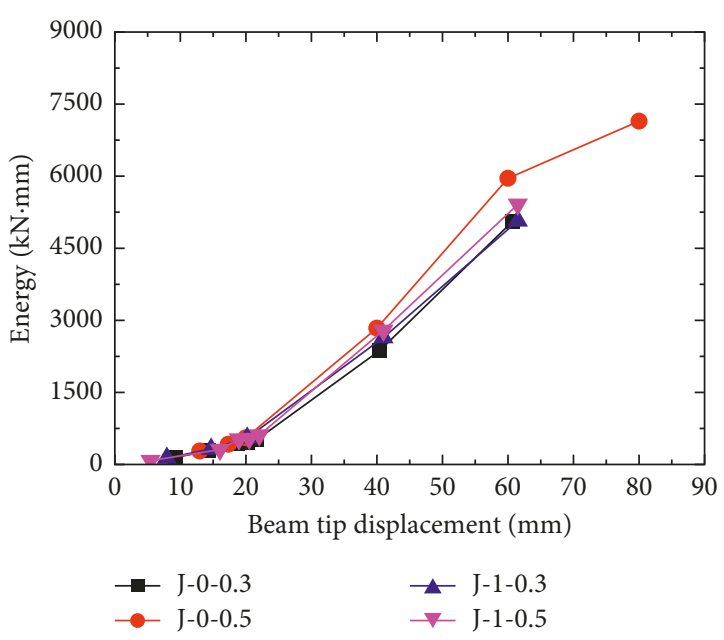

FIGURE 11: Energy dissipation of joint specimens.

area of RPC. $V_{j}$ is the shear carrying capacity of RPC joint, which can be calculated by $(2) ; f_{c}$ is the compressive strength of RPC; $b_{j}$ is the width of joint; and $h_{j}$ is the height of joint.

The influence of axial compression ratio and stirrup ratio to shear-compression ratio is shown in Figure 12. The shearcompression ratio of specimen J-1-0.3 increased by $7.9 \%$ as compared to $\mathrm{J}-0-0.3$, and the shear-compression ratio of specimen J-1-0.5 decreased by $2.3 \%$ as compared to J-0-0.5. This could be explained by the fact that yield of stirrup in joint core was found before peak load. For specimens J-1-0.3 and
J-1-0.5, there was only a double-leg loop with a $6 \mathrm{~mm}$ diameter in the joints, so the restriction effect on RPC was weaker and the enhance effect of the shear strength was not obvious. Under the same axial compression ratio, The stirrups in the joints play a role in constraining the concrete of joint core, which can improve the compressive and shear strength of concrete; besides, stirrups in the joint core can bear directly part of the shear force of joint; thus, it can effectively improve the shear strength of the joint by configuring a number of stirrups [5]. It is necessary to use a certain amount stirrups in RPC joint core even though RPC joint has high strength and ductility. Under the same reinforcement condition, the shear-compression ratio of specimen J-0-0.5 increased by $18.1 \%$ as compared to $\mathrm{J}-0-0.3$, and the shear-compression ratio of J-1-0.5 increased by $6.9 \%$ as compared to J-1-0.3. The cracking resistance of concrete can be improved by increasing the axial compression ratio. The microcracks in concrete can reclose under the axial compressive force, and it is beneficial for improving the shear strength of concrete by properly increasing the axial compressive force within a certain range. A similar behavior was reported by other researchers $[8,26,27]$ in which the joint shear strength moderately increases as the axial load level increases within a certain range. On the other hand, the increase in the axial compressive force can reduce ductility of beam-column joint. $\mathrm{Li}$ and Leong [27] reported that any increase in the column axial compressive load beyond $0.3 f_{c}^{\prime} A_{g}$ did not improve the shear strength, and the application of column axial compression ratios above 0.3 causes a decrease in shear strength and a degradation of rigidity. Kim and Lafave [28] reported 
TABLE 6: Test results and analysis.

\begin{tabular}{|c|c|c|c|c|c|c|c|}
\hline \multirow{2}{*}{ Specimen number } & \multirow{2}{*}{ Stirrup } & \multirow{2}{*}{ Axial compression ratio } & \multirow{2}{*}{ Test value $(\operatorname{Exp} / \mathrm{kN})$} & \multicolumn{4}{|c|}{ Calculation value of shear strength $(\mathrm{kN})$} \\
\hline & & & & GB 50010-2010 & Exp/GB & ACI $318-14$ & Exp/ACI \\
\hline $\mathrm{J}-0-0.3$ & 0 & 0.3 & 374.82 & 250.116 & 1.50 & 308.192 & 1.22 \\
\hline $\mathrm{J}-0-0.5$ & 0 & 0.5 & 410.21 & 251.841 & 1.63 & 296.727 & 1.38 \\
\hline $\mathrm{J}-1-0.3$ & 1 & 0.3 & 380.91 & 259.118 & 1.47 & 299.14 & 1.27 \\
\hline $\mathrm{J}-1-0.5$ & 1 & 0.5 & 379.21 & 261.665 & 1.45 & 288.636 & 1.31 \\
\hline
\end{tabular}

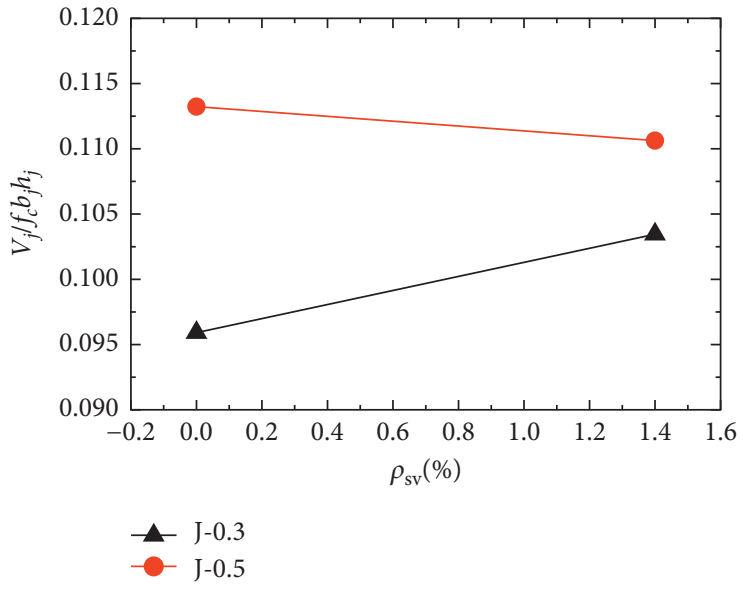

(a)

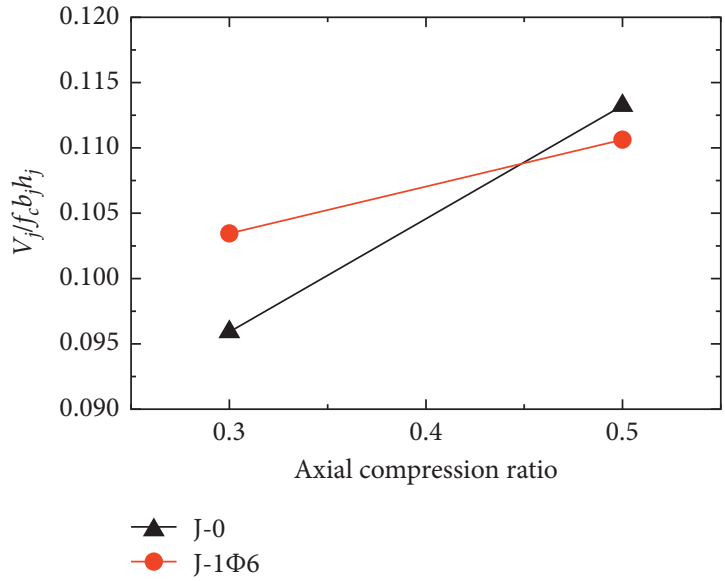

(b)

Figure 12: Influence of axial compression ratio and stirrup ratio to shear-compression ratio. (a) Stirrup ratio of joint core. (b) Axial compression ratio.

that the column axial compression ratio had little influence on the joint shear behavior.

Based on the test results of the mechanical properties of reinforced bars and RPC, the shear strength of joint specimens were calculated according to the China code for seismic design of buildings (GB50011-2010) [23] and ACI 318-14 (in accordance with ACI R352-02 committee report) [29], respectively. The calculated results of the shear strength were lower than those of the test result. The calculated value using GB50011-2010 was lower than that using ACI 318-14, and the test value was about 1.51 times larger than the value calculated by GB50011-2010 and was about 1.30 times larger than the value calculated by ACI 318-14. The comparison is not satisfactory; this may be due to the following reasons. RPC has higher compressive strength; however, the tensioncompression ratio of the RPC is smaller than that of ordinary concrete. The tensile strength $f_{t}$ of concrete is used as representative value of shear strength in the China code, and the compressive strength's square root $\left(\sqrt{f_{c}^{\prime}}\right)$ of concrete is used as the representative value of shear strength in ACI 318-14. Thus, the value calculated by the China code is smaller than the value calculated by ACI 318-14. The test result indicates that the shear force in the RPC joint is mainly carried by the diagonal strut mechanism, which is consistent with design expression of ACI 318-14; the shear strength test results were found to be $22 \% \sim 38 \%$ more than the value calculated by ACI 318-14. So the design expressions $V_{j}=\alpha_{a c i, j} \lambda_{a c i, j} \sqrt{f_{c}^{\prime}} A_{j}$ can be used for calculating the shear strength of RPC joints.

\section{Conclusions}

(1) Reinforced RPC beam-column joints have a higher shear-cracking strength and shear bearing capacity and strength reduction and rigidity degradation are slow. The use of RPC for beam-column joints can reduce the congestion of stirrups in joints core.

(2) Within the range of the axial compression ratio in this test, the energy dissipation capacities of the beam-column joints increase with the axial compression ratio increases.

(3) The shear force in the RPC joint is mainly carried by the diagonal strut mechanism. The stirrup in the joint core can improve strength of diagonal strut and the energy dissipation of joints.

\section{Conflicts of Interest}

The authors declare that there are no conflicts of interest regarding the publication of this paper.

\section{Acknowledgments}

The work described in this paper was fully supported by the National Natural Science Foundation of China (Project no. 51378095). The authors would like to thank the staff in the Structural engineering lab of Northeast Electric Power University for their kind assistance during the tests. 


\section{References}

[1] N. W. Hanson and H. W. Conner, "Seismic resistance of reinforced concrete beam-column joints," Journal of the Structural Division American Society of Civil Engineers, vol. 93, no. 5, pp. 533-559, 1967.

[2] T. Paulay and M. J. N. Priestley, Seismic Design of Reinforced Concrete and Masonry Buildings, Wiley, New York, NY, USA, 1992.

[3] S. A. Attaalla, "General analytical model for nominal shear stress of type 2 normal- and high-strength concrete beamcolumn joints," ACI Materials Journal, vol. 101, no. 6, pp. 65-75, 2004.

[4] S. J. Hwang and H. J. Lee, "Strength prediction for discontinuity regions by softened strut-and-tie model," Journal of Structural Engineering, vol. 128, no. 12, pp. 1519-1526, 2002.

[5] J. R. Tang, C. B. Hu, K. J. Yang, and Y. Yongcheng, "Seismic behaviour and shear strength of framed joint using steel-fiber reinforced concrete," Journal of Structural Engineering, vol. 118, no. 2, pp. 341-358, 1992.

[6] H. Ibrahim, Stud Reinforcement in Beam-Column Joints under Seismic Loads, University of Calgary, Calgary, AB, Canada, 2011.

[7] G. Kotsovou and M. Harris, "Exterior RC beam-column joints: new design approach," Engineering Structures, vol. 41, pp. 307-319, 2012.

[8] X. Liang, Y. Wang, Y. Tao, and M. K. Deng, "Seismic performance of fiber-reinforced concrete interior beam-column joints," Engineering Structures, vol. 126, pp. 432-445, 2016.

[9] A. Filiatrault, K. Ladicani, and B. Massicotte, "Seismic performance of code-designed fiber reinforced concrete joints," ACI Materials Journal, vol. 91, no. 5, pp. 564-571, 1994.

[10] Z. Bayasi and M. Gebman, "Reduction of lateral reinforcement in seismic beam-column connection via application of steel fibers," ACI Structural Journal, vol. 99, no. 6, pp. 772-780, 2002.

[11] P. Richard and M. Cheyrezy, "Composition of reactive powder concretes," Cement \& Concrete Research, vol. 25, no. 7, pp. 1501-1511, 1995.

[12] R. Yu, P. Spiesz, and H. J. H. Brouwers, "Development of an eco-friendly Ultra-High Performance Concrete (UHPC) with efficient cement and mineral admixtures uses," Cement \& Concrete Composites, vol. 55, no. 1, pp. 383-394, 2015.

[13] N. Roux, C. Andrade, and M. A. Sanjuan, "Experimental study of durability of reactive powder concretes," Journal of $M a$ terials in Civil Engineering, vol. 8, no. 1, pp. 1-6, 1996.

[14] B. Graybeal and J. Tanesi, "Durability of an ultrahighperformance concrete," Journal of Materials in Civil Engineering, vol. 19, no. 10, pp. 848-854, 2007.

[15] H. Yiğiter, S. Aydın, H. Yazıcı, and M. Y. Yardımc1, "Mechanical performance of low cement reactive powder concrete (LCRPC)," Composites Part B Engineering, vol. 43, no. 8, pp. 2907-2914, 2012.

[16] S. Ahmad, A. Zubair, and M. Maslehuddin, "Effect of key mixture parameters on flow and mechanical properties of reactive powder concrete," Construction \& Building Materials, vol. 99, no. 11, pp. 73-81, 2015.

[17] C. C. Hung and C. Y. Chueh, "Cyclic behavior of UHPFRC flexural members reinforced with high-strength steel rebar," Engineering Structures, vol. 122, no. 9, pp. 108-120, 2016.

[18] A. R. Malik and S. J. Foster, "Carbon fiber-reinforced polymer confined reactive powder concrete columns-experimental investigation," ACI Structural Journal, vol. 107, no. 3, pp. 263-271, 2010.
[19] Z. Deng, C. Chen, and X. Chen, "Experimental research on the shear behaviors of hybrid fiber reinforced RPC beams," China Civil Engineering Journal, vol. 48, no. 5, pp. 51-60, 2015.

[20] D. H. Wang, Y. Z. Ju, and W. Z. Zheng, "Strength of reactive powder concrete beam-column joints reinforced with highstrength (HRB600) bars under seismic loading," Strength of Materials, vol. 49, no. 1, pp. 139-151, 2017.

[21] Y. Z. Ju, D. H. Wang, and J. Bai, "Seismic performance of reactive powder concrete columns," Journal of Harbin Institute of Technology, vol. 45, no. 8, pp. 111-116, 2013.

[22] W. Zhou, H. Hu, and W. Zheng, "Bearing capacity of reactive powder concrete reinforced by steel fibers," Construction \& Building Materials, vol. 48, no. 19, pp. 1179-1186, 2013.

[23] GB 50011-2010, Code for Seismic Design of Buildings, China Building Industry Press, Beijing, China, 2010.

[24] JGJ 101-96, Specificating of Testing Methods for Earthquake Resistant Building, China Building Industry Press, Beijing, China, 1997.

[25] B. Zhu, Structure Seismic Test, Seismological Press, Beijing, China, 1989.

[26] P. Alaee and B. Li, "High-strength concrete interior beamcolumn joints with high-yield-strength steel reinforcements," Journal of Structural Engineering, vol. 143, no. 7, p. 04017038, 2017.

[27] B. Li and C. L. Leong, "Experimental and numerical investigations of the seismic behavior of high-strength concrete beam-column joints with column axial load," Journal of Structural Engineering, vol. 141, no. 9, p. 04014220, 2015.

[28] J. Kim and J. M. Lafave, "Key influence parameters for the joint shear behaviour of reinforced concrete (RC) beamcolumn connections," Steel Construction, vol. 29, no. 10, pp. 2523-2539, 2007.

[29] ACI 318-14, Building Code Requirements for Structural Concrete and Commentary, American Concrete Institute, Farmington Hills, MI, USA, 2014. 


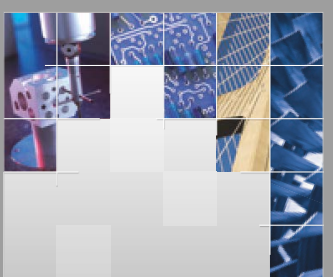

\section{Enfincering}
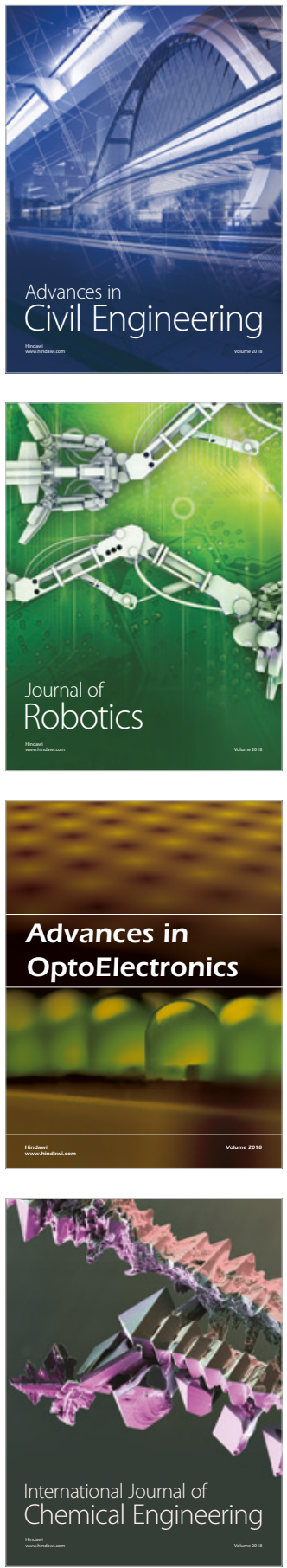

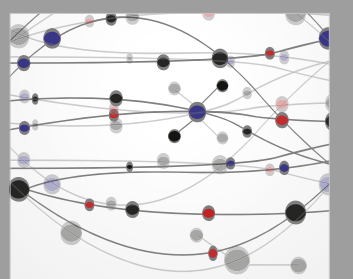

\section{Rotating \\ Machinery}

The Scientific World Journal

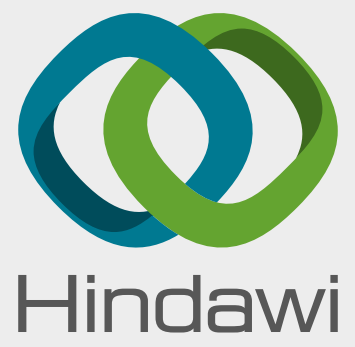

Submit your manuscripts at

www.hindawi.com
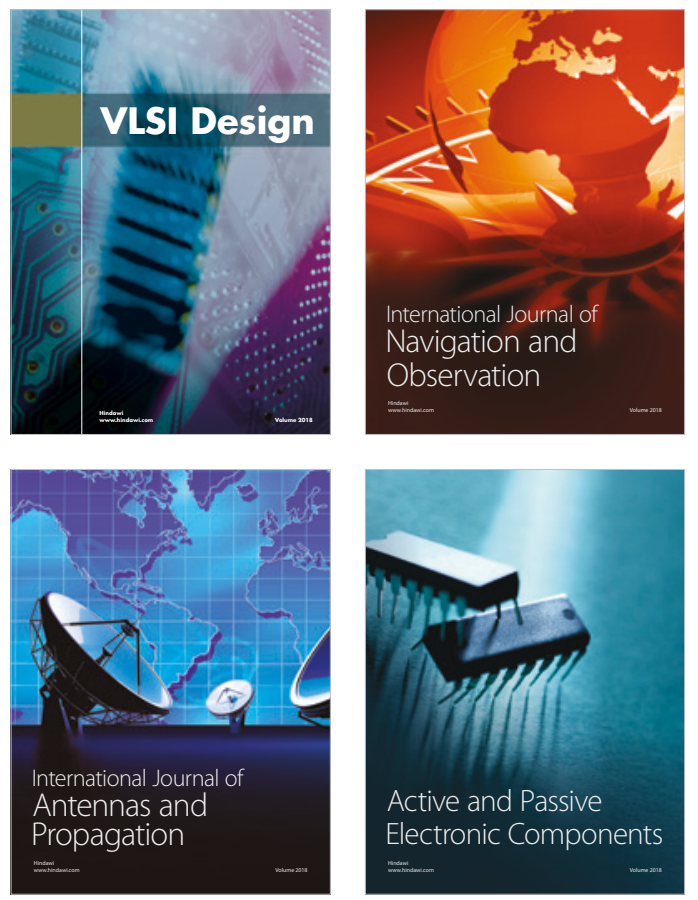
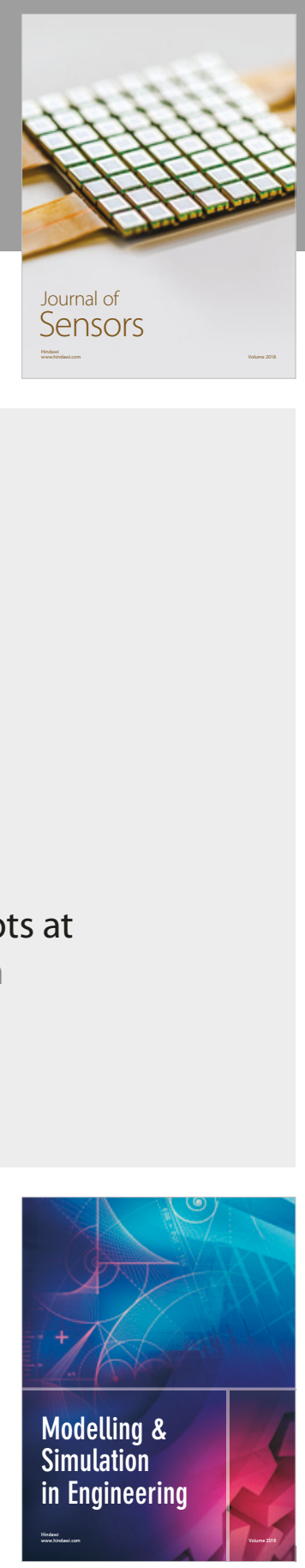

\section{Advances \\ Multimedia}
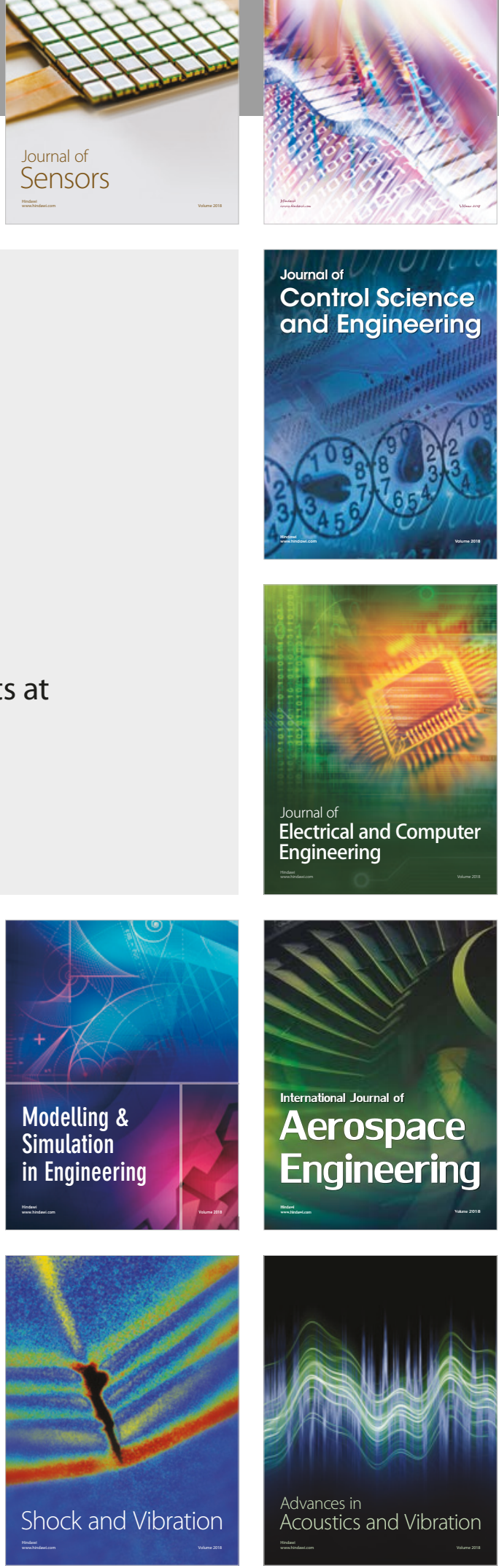